\title{
A putative integrase gene defines the distal end of a large cluster of ToxR-regulated colonization genes in Vibrio cholerae
}

\author{
Michael E. Kovach, Megan D. Shaffer and Kenneth M. Peterson \\ Author for correspondence: Kenneth M. Peterson. Tel: +1318 675 5753. Fax: +1 3186755764. \\ e-mail: kpeter $(\mathcal{C}$ pop3.lsumc.edu
}

Department of Microbiology and Immunology, Louisiana State University Medical Center-Shreveport, Shreveport, LA 71130, USA

\begin{abstract}
A large cluster of virulence genes encoding proteins involved in Vibrio cholerae accessory colonization factor (ACF) expression and toxin-coregulated pilus (TCP) biogenesis is flanked by sequences that resemble bacteriophage attachment (att) half-sites. Adjacent to the attL-like site is a gene (int) that encodes a protein related to the integrase family of site-specific recombinases. The putative vibrio integrase appears to be most closely related to the Escherichia coli cryptic prophage (CP4-57) integrase protein (52\% identity, $73 \%$ similarity). Genomic analysis of numerous $V$. cholerae strains (01, non-01 and 0139) revealed that only vibrios capable of causing epidemic Asiatic cholera possess the TCP-ACF colonization gene cluster in association with the integrase. The fact that the integrase gene is absent in avirulent strains suggests that epidemic strains of $\boldsymbol{V}$. cholerae obtained the TCP-ACF colonization gene cluster via horizontal transfer.
\end{abstract}

Keywords: Vibrio cholerae, colonization, integrase, ToxR regulon, mobile genetic element

\section{INTRODUCTION}

Vibrio cholerae, a Gram-negative bacterium, is the etiological agent of the severe diarrhoeal disease Asiatic cholera. This syndrome results from the ingestion of food or water contaminated with the bacterium, followed by colonization of the small bowel and the subsequent secretion of cholera toxin (CTX) by the vibrios. Intraintestinal survival of $V$. cholerae is a poorly understood process requiring the expression of a number of coordinately regulated virulence factors (DiRita, 1992) in order to overcome the host's natural defence mechanisms. Prior to intestinal colonization the vibrios must survive exposure to the gastric acid of the stomach, localize in the small bowel, and penetrate the mucous gel protecting the intestinal microvilli. Following penetration of the protective mucous gel, the vibrios colonize the epithelial cell surface of the microvilli. At some point in the colonization process, the synthesis of CTX, toxin-coregulated pilus (TCP) (Taylor et al., 1987) and an additional accessory colonization factor (ACF) (Peterson \& Mekalanos, 1988) occurs. Production of TCP and ACF enhance the ability

Abbreviations: ACF, accessory colonization factor; $C T X$, cholera toxin: $T C P$, toxin-coregulated pilus.

The GenBank accession number for the nucleotide sequence reported in this paper is 002372 . of $V$. cholerae to successfully colonize the intestinal epithelium (Taylor et al., 1987; Peterson \& Mekalanos, 1988). Recent studies have shown that the tcp and acf gene clusters are physically linked on the $V$. cholerae chromosome, suggesting that the TCP and ACF factors may interact in some manner to promote successful colonization of the small bowel (Everiss et al., 1994a, b). The action of CTX triggers the characteristic, profuse diarrhoea associated with this disease, promoting dissemination of the organisms back into the environment. Synthesis of CTX, TCP and ACF are controlled at the transcriptional level by a DNA-binding protein, ToxR, in response to environmental stimuli (Miller \& Mekalanos, 1988). Transcriptional activation of these $V$. cholerae virulence genes can occur either directly by ToxR binding to the heptanucleotide T'TTTGAT (Miller \& Mekalanos, 1984), or indirectly via ToxR-regulated control of a second transcriptional activator, ToxT (DiRita et al., 1991 ; DiRita, 1992). Tox'T is a member of the AraC family of transcriptional activators that regulates the expression of a number of genes involved in $V$. cholerae virulence ( $\operatorname{acf} A, \operatorname{tcp} A, \operatorname{tcp} C$ and $t c p I)$ as well as several genes whose roles in virulence have not been established (ald $A$ and tag A) (DiRita et al., 1991; DiRita, 1992; Higgins et al., 1992; Parsot \& Mekalanos, 1991, 1992). The activation of $V$. cholerae virulence factors by ToxT, a transcriptional activator dependent on Tox $\mathrm{R}$ for expression, represents 
an environmentally responsive regulatory cascade that is responsible for the coordinate activation of genes involved in $V$. cholerae colonization of the small bowel (DiRita, 1992). These genes belong to the ToxR regulon and are referred to as ToxR-activated genes (TAGs) (Peterson \& Mekalanos, 1988).

In numerous pathogenic bacteria virulence genes have been identified on mobile genetic elements, which may facilitate transfer of these genes between bacterial species (Finlay \& Falkow, 1989). Work by Pearson et al. (1993) has demonstrated that the $V$. cholerae CTX genes encode two additional toxins: the zonula occludens toxin (zot) (Fasano et al., 1991; Baudry et al., 1992) and an accessory cholera enterotoxin (ace) (Trucksis et al., 1993). Both these toxins, as well as a core encoded pilin (cep), are located within a mobile genetic element. Karaolis et al. (1995) have inferred, based on polymorphism within the $V$. cholerae housekeeping gene encoding the aspartate-semialdehyde dehydrogenase (asd), that horizontal transfer of the $V$. cholerae $\mathrm{O}$ antigen genes may occur, suggesting that $V$. cholerae could show a high level of intraspecies genetic exchange. Additionally, the atypical $V$. cholerae codon usage for the genes within the TCP locus has led to the proposal that the TCP gene cluster may be part of a larger genetic element (Ogierman \& Manning, 1992; Kaufman et al., 1993).

In this report, we describe the identification of a $V$. cholerae gene, int, that encodes a protein related to the integrase family of site-specific recombinases. The $V$. cholerae int is the distal marker for a DNA segment of greater than $45 \mathrm{kbp}$ encoding the $V$. cholerae ToxRactivated colonization determinants TCP and ACF. The data presented herein showing the physical linkage of the integrase gene to the ACF and TCP gene clusters supports the hypothesis that these colonization factors are part of a large genetic element involved in intestinal colonization that may have been, at one time, part of a mobile element acquired by $Y$. cholerae.

\section{METHODS}

Bacterial strains, phages, plasmids, media and reagents. The bacterial strains, phages and plasmids used in this study are listed in Table 1. Non-O1 strains of $V$. cholerae other than O139 have been referred to as 'nonagglutinating' or 'noncholera' vibrios and are typically not associated with epidemic cholera (Morris, 1990). Escherichia coli and Vibrio cholerae strains were maintained at $-70^{\circ} \mathrm{C}$ in Luria-Bertani (LB) medium containing $20 \%(\mathrm{v} / \mathrm{v})$ glycerol (Miller, 1972). E. coli strains were cultured in $\mathrm{LB}$ broth or on $\mathrm{LB}$ agar at $37^{\circ} \mathrm{C}$. $V$. cholerae strains were cultured on LB agar at $37^{\circ} \mathrm{C}$ or in LB broth pH 6.5 at $30^{\circ} \mathrm{C}$ or LB broth pH 8.4 at $37^{\circ} \mathrm{C}$ as previously described (Peterson \& Mekalanos, 1988). Antibiotics, when necessary, were used at the following concentrations: ampicillin (Ap) $100 \mu \mathrm{g} \mathrm{m}^{-1}$, kanamycin $(\mathrm{Km}) 30 \mu \mathrm{g} \mathrm{ml}^{-1}$ and streptomycin $(\mathrm{Sm}) 100 \mu \mathrm{g} \mathrm{ml}^{-1}$. Restriction endonucleases were purchased from New England Biolabs and T4 DNA ligase was purchased from Promega. Enzymes were used according to the manufacturers' recommendations. Isotopes, $\left[{ }^{35} \mathrm{~S}\right] \mathrm{dATP} \alpha \mathrm{S}$ and $\left[{ }^{32} \mathrm{P}\right] \mathrm{dATP}$ were purchased from Amersham. All other biochemical reagents were purchased from Sigma unless otherwise stated. Restriction analysis, plasmid construction and molecular biology techniques were performed according to standard procedures (Ausubel $e t$ al., 1989; Sambrook et al., 1989). Reagents used in RNA preparation and analysis were treated with diethyl pyrocarbonate (DEPC) prior to use.

Genomic DNA isolation and analysis. Genomic DNA was isolated from $1.5 \mathrm{ml}$ overnight cultures of $V$. cholerae (Ausubel et al., 1989). $V$. cholerae cells were harvested by centrifugation and resuspended in $567 \mu \mathrm{l} \mathrm{TE}(10 \mathrm{mM}$ Tris $\mathrm{pH} 8.0 / 1 \mathrm{mM}$ EDTA). SDS [ $30 \mu \mathrm{l}, 10 \%(\mathrm{w} / \mathrm{v})$ solution] and proteinase $\mathrm{K}$ $\left(3 \mu \mathrm{l}, 20 \mathrm{mg} \mathrm{m}^{-1}\right.$ solution) were added, giving final concentrations of $100 \mu \mathrm{g}$ proteinase $\mathrm{K} \mathrm{ml}^{-1}$ and $0.5 \%$ SDS in $600 \mu \mathrm{l}$ TE. After incubation at $37^{\circ} \mathrm{C}$ for $1 \mathrm{~h}$, one-sixth vol. $5 \mathrm{M} \mathrm{NaCl}$ was added and the sample was mixed by inversion. Cetyltrimethylammonium bromide $(\mathrm{CTAB}) / \mathrm{NaCl}$ solution $[80 \mu \mathrm{l}$, $10 \%(\mathrm{w} / \mathrm{v}) \mathrm{CTAB}$ in $0.7 \mathrm{M} \mathrm{NaCl}$ was added to the sample, mixed by inversion and incubated at $65^{\circ} \mathrm{C}$ for $10 \mathrm{~min}$. The solution was extracted once with an equal volume of chloroform/isoamyl alcohol, and once with an equal volume of phenol/chloroform. The DNA was precipitated by adding 0.6 vol. isopropyl alcohol and the chromosomal DNA was collected on a glass rod. The DNA was washed once with $70 \%$ $(\mathrm{v} / \mathrm{v})$ ethanol and resuspended in TE buffer $\mathrm{pH} 8 \cdot 0$.

DNA manipulations and analysis. Chromosomal DNA used in slot blot analysis was denatured at $100^{\circ} \mathrm{C}$ in $0.4 \mathrm{M}$ $\mathrm{NaOH} / 10 \mathrm{mM}$ EDTA for $10 \mathrm{~min}$ and applied to Hybond $\mathrm{N}+$ filters (Amersham) under alkaline conditions (Ausubel $e t$ al., 1989). Chromosomal DNA used in Southern analysis was digested with $D r a \mathrm{I}$, size-fractionated on a $1 \cdot 2 \%(\mathrm{w} / \mathrm{v})$ agarose gel in $1 \times$ TAE (40 mM Tris, $40 \mathrm{mM}$ acetic acid, $2 \mathrm{mM}$ EDTA, $\mathrm{pH} 8.0)$ and transferred to a BioBlot-N + membrane (Costar) by capillary transfer in $10 \times \mathrm{SSC}(1 \times \mathrm{SSC}: 0 \cdot 15 \mathrm{M}$ sodium chloride, $0 \cdot 015 \mathrm{M}$ sodium citrate, $\mathrm{pH} 7 \cdot 0)$. Filters were baked for $2 \mathrm{~h}$ in vacuo at $80^{\circ} \mathrm{C}$ and prehybridized for $2 \mathrm{~h}$ in $6 \times \mathrm{SSPE}$ $(1 \times$ SSPE: $150 \mathrm{mM} \mathrm{NaCl}, 10 \mathrm{mM}$ sodium phosphate, $1 \mathrm{mM}$ EDTA, pH 7.4), $5 \times$ Denhardt's solution $[0 \cdot 1 \%$ Ficoll ('Type 400), $0 \cdot 1 \%$ polyvinylpyrrolidone, $0 \cdot 1 \%$ bovine serum albumin (Fraction V)], $0.5 \%$ SDS, $50 \%(\mathrm{v} / \mathrm{v})$ formamide and $100 \mu \mathrm{g}$ denatured herring sperm DNA ml ${ }^{-1}$ at $42{ }^{\circ} \mathrm{C}$. The DNA probes used in this study were derived as follows: $\operatorname{tag} D$-specific probe, $0.7 \mathrm{kbp}$ DraI fragment from pTAGD-1; tcpI-specific probe, $\sim 1.0 \mathrm{kbp} E c o \mathrm{RV}$ fragment from pTCPI-1; toxT-spec-

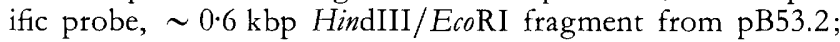
acf-specific probe, $\sim 4.2 \mathrm{kbp} S a c \mathrm{I}$ fragment from pMEK2; intspecific probe, $\sim 1.3 \mathrm{kbp} E c o \mathrm{RV}$ fragment from pMEK3; ssr $A$-specific probe, $\sim 1.3 \mathrm{kbp} D r a \mathrm{I}$ fragment from pMEK3; and the probe derived from $V$. cholerae $\mathrm{SG} 34$ downstream of the ssr $A$ gene that was used as a probe, $\sim 3.0 \mathrm{kbp} S a c \mathrm{I} / B g / \mathrm{II}$ fragment from $\phi 19$. DNA restriction fragments used as probes in Southern analysis were isolated by agarose gel electrophoresis, purified using GeneClean (Bio101) and labelled with $\left[{ }^{32} \mathrm{P}\right] \mathrm{dATP}$ using a random primer labelling kit (Promega). The unincorporated nucleotides were removed from the oligonucleotide probes by G- 50 spin-column purification (Sambrook et al., 1989). The radiolabelled probe was heated for $5 \mathrm{~min}$ at $100{ }^{\circ} \mathrm{C}$ and added to the prehybridizing filters. Hybridization was continued overnight at $42{ }^{\circ} \mathrm{C}$. The filters were washed as follows: $5 \mathrm{~min}$ in $2 \times \mathrm{SSC} / 0.5 \%$ SDS at room temperature, $15 \mathrm{~min}$ in $2 \times \mathrm{SSC} / 0.1 \% \mathrm{SDS}$ at room temperature, $2 \mathrm{~h}$ in $0.1 \times$ SSC $/ 0.5 \%$ SDS at $68{ }^{\circ} \mathrm{C}$ and $30 \mathrm{~min}$ in $0.2 \times \mathrm{SSC} / 0.1 \%$ SDS at $68{ }^{\circ} \mathrm{C}$. The washed filters were air-dried and exposed to Kodak $\mathrm{X}$-OMAT film at $-70^{\circ} \mathrm{C}$ with an intensifying screen (Fisher Scientific) for 4-16 h.

RNA isolation and analysis. Overnight cultures of $V$. cholerae were grown under ToxR-repressing conditions, in $\mathrm{LB} \mathrm{pH} 8.4$ at 
Table 1. Bacteria, phages and plasmids used in this study

\begin{tabular}{|c|c|c|}
\hline Strain or plasmid & Relevant genotype or characteristics & Reference or source \\
\hline \multicolumn{3}{|l|}{ Strains } \\
\hline \multicolumn{3}{|l|}{$V$ cholerae } \\
\hline O395 & O1, classical/Ogawa, $\mathrm{Sm}^{\mathrm{R}}$ & Laboratory stock \\
\hline KP1.17 & $\mathrm{O} 395$ tox $\mathrm{R}:: \mathrm{pVM} 55, \mathrm{Ap}^{\mathrm{R}}, \mathrm{Sm}^{\mathrm{R}}$ & Laboratory stock \\
\hline C6709 & O1, El Tor/Inaba, $\mathrm{Sm}^{\mathrm{R}}$ & Peru* \\
\hline 0872 & O1, El Tor/Inaba & Peru*f \\
\hline $\mathrm{ANCO} 223$ & O1, El Tor/Ogawa & Peru* \\
\hline P27459 & O1, El Tor/Inaba, $\mathrm{Sm}^{\mathbf{R}}$ & Bangladesh* \\
\hline E7946 & O1, El Tor/Ogawa, $\mathrm{Sm}^{\mathrm{R}}$ & Bahrain* \\
\hline AI4456 & Non-O1, $\mathrm{Sm}^{\mathrm{R}}$, non-motile & Bangladesh*† \\
\hline AI1837 & $\mathrm{O} 139, \mathrm{Sm}^{\mathrm{R}}$ & Bangladesh* \\
\hline $\mathrm{MO} 2$ & $\mathrm{O} 139, \mathrm{Sm}^{\mathrm{R}}$ & India* \\
\hline MO10 & O139 & India* \\
\hline SG34 & O56 & Waldor \& Mekalanos (1994) \\
\hline VO7 & $\mathrm{O} 37$ & Waldor \& Mekalanos (1994) \\
\hline $1074-78$ & O1, El Tor/Ogawa, nonpathogenic & Levine et al. (1982) \\
\hline $1196-78$ & O1, El Tor/Ogawa, nonpathogenic & Levine et al. (1982) \\
\hline \multicolumn{3}{|l|}{ E. coli } \\
\hline JM109 & $\begin{array}{l}\mathrm{F}^{\prime} \operatorname{traD} 36 \text { lacl }^{q} \Delta(\operatorname{lac} Z) \mathrm{M} 15 \text { pro } A B / \operatorname{rec} A 1 \\
\text { end } A 1 \operatorname{gyr} A 96\left(\mathrm{Nal}^{\mathrm{R}}\right) \text { thi bsdR } 17\left(\mathrm{r}_{\mathrm{k}}^{-}, \mathrm{m}_{\mathrm{k}}^{+}\right) \\
\sup \mathrm{E} 44(\operatorname{mcr} A) \operatorname{rel} A 1 \Delta(\text { lac-pro } A B)\end{array}$ & Promega \\
\hline \multicolumn{3}{|l|}{ Plasmids } \\
\hline pUC18 & $\operatorname{lac} Z^{\prime}, A p^{R}$ & Yanisch-Perron et al. (1985) \\
\hline pBluescript II $\mathrm{KS}^{+}$ & $\operatorname{lac} Z^{\prime}, \mathrm{Ap}^{\mathrm{R}}$ & Stratagene \\
\hline pMEK1 & $\begin{array}{l}\text { pUC18 containing } 16 \mathrm{kbp} \text { Sal I fragment } \\
\text { from } \phi \mathrm{A} 13, \mathrm{Ap}^{\mathrm{R}}\end{array}$ & This study \\
\hline pMEK2 & $\begin{array}{l}\text { pUC18 con ning } \sim 4.2 \mathrm{kbp} a c f C^{+} S a c \mathrm{I} \\
\text { fragment } \ldots \text { m } \phi \mathrm{A} 13, \mathrm{Ap}^{\mathrm{R}}\end{array}$ & This study \\
\hline pMEK3 & $\begin{array}{l}\text { pBluescript II } \mathrm{KS}^{+} \text {containing } \sim 4 \cdot 4 \mathrm{kbp} \\
\text { Bam HI fragment from pMEK1, Ap }\end{array}$ & This study \\
\hline pB53.2 & $\begin{array}{l}\text { pLC18 containing } 11 \mathrm{kbp} E c o \mathrm{RV} / \text { Bam HI } \\
\text { fragment containing the Tnpbo } A \text { fusion } \\
\text { junction from KP3.51(acfB:: Tnpho } A) \\
A \mathrm{p}^{\mathrm{R}}, \mathrm{Km}^{\mathrm{R}}\end{array}$ & Everiss et al. (1994a) \\
\hline pTAGD-1 & pBluescript II containing $V$. cholerae tagD & Hughes et al. (1994) \\
\hline p'TCPI-1 & pBluescript II containing $V$. cholerae tcpI & Harkey et al. (1994) \\
\hline pVM55 & pJM703.1::EcoRI-HpaI $(t o x R), A_{p^{R}}$ & Miller \& Mekalanos (1988) \\
\hline \multicolumn{3}{|l|}{ Bacteriophage } \\
\hline$\lambda \mathrm{GEM}-11$ & Lambda replacement cloning vector & Promega \\
\hline$\phi \mathrm{A} 13$ & $\begin{array}{l}2 \text { GEM- } 11 \text { containing } 16 \mathrm{kbp} \text { acf }{ }^{+} \text {partial } \\
\text { Sau3A fragment from } V \text {. cholerae } \mathrm{O} 395\end{array}$ & This study \\
\hline$\phi 19$ & $\begin{array}{l}\lambda \mathrm{GEM}-11 \text { containing } \sim 16 \mathrm{kbp} s s \mathrm{~A} A^{+} \\
\text {partial Sau3A fragment from } V . \text { cholerae } \\
\text { SG34 }\end{array}$ & This study \\
\hline$\phi \mathrm{D} 12-2$ & $\begin{array}{l}\text { 2GEM-11 containing } \sim 16 \mathrm{kbp} \text { tag } D^{+} \\
\text {partial Sau3A fragment from } L \text {. cholerae } \\
\text { O395. }\end{array}$ & This study \\
\hline
\end{tabular}

* Recovered from patients with cholera.

$\dagger$ Serogroup has not been confirmed.

$37^{\circ} \mathrm{C}$. These cultures were washed once with an equivalent volume of PBS (Ausubel et al., 1989) pH 7.2, resuspended in an equal volume of LB pH 6.5 and diluted 1:100 in $50 \mathrm{ml} \mathrm{LB}$ $\mathrm{pH} 6.5$ (optimal conditions for the expression of ToxR-activated genes) (Peterson \& Mekalanos, 1988) and grown with aeration for $4 \mathrm{~h}$ at $30^{\circ} \mathrm{C}\left(\mathrm{OD}_{600} \sim 1 \cdot 0\right)$. Total RNA was isolated from these cultures using the hot phenol method (Aiba et al., 1981). Isolated RNA was purified by centrifugation through a $\mathrm{CsCl}$ 
gradient (Ausubel et al,, 1989), quantitated spectrophotometrically and stored in diethyl-pyrocarbonate-treated water at $-70^{\circ} \mathrm{C}$. Total RNA from each $V$. cholerae strain was denatured in $50 \%$ formamide at $65^{\circ} \mathrm{C}$ for $10 \mathrm{~min}$ and applied to nitrocellulose filters under high salt conditions (Ausubel et al., 1989). Nitrocellulose filters containing the transferred RNA were equilibrated in $5 \times \mathrm{SSC}$ for $15 \mathrm{~min}$, air-dried, baked in vacuo at $80^{\circ} \mathrm{C}$ for $2 \mathrm{~h}$ and prehybridized for $1 \mathrm{~h}$ in $6 \times \mathrm{SSPE}$, $0.5 \%$ SDS, $5 \times$ Denhardt's solution, $50 \%$ formamide with $100 \mu \mathrm{g}$ herring sperm DNA ml${ }^{-1}$ at $42^{\circ} \mathrm{C}$. Radiolabelled probes were added and hybridization continued overnight at $42{ }^{\circ} \mathrm{C}$. The filters were washed for $5 \mathrm{~min}$ at room temperature in $1 \times \mathrm{SSC} / 0.1 \% \mathrm{SDS}$, followed by three $20 \mathrm{~min}$ washes at $68^{\circ} \mathrm{C}$ in $0.2 \times \mathrm{SSC} / 0.1 \%$ SDS. The washed filters were air-dried and exposed to Kodak X-OMAT film at $-70{ }^{\circ} \mathrm{C}$ with an intensifying screen for 4-16 h.

DNA sequencing. The DNA sequence was determined by the dideoxy chain-termination method (Sanger et al., 1977), using synthesized complementary oligonucleotide primers (Integrated DNA Technologies), $\left[{ }^{35} \mathrm{~S}\right] \mathrm{dATP} \alpha \mathrm{S}$ and a Sequenase kit (United States Biochemical) following the manufacturers' protocols. The nucleic acid and the deduced protein sequence were analysed using the MacVector sequence analysis software (International Biotechnologies). Protein and nucleic acid similarity searches were performed against the non-redundant databases using the National Center for Biotechnology Information (NCBI) network server and the BLAST algorithm (Altschul et al., 1990).

\section{RESULTS}

\section{Transcriptional analysis of genes downstream of the ACF gene cluster}

We have previously shown that the TCP and ACF gene clusters are physically linked on the $V$. cholerae chromosome and encompass greater than $20 \mathrm{kbp}$ of contiguous DNA sequence encoding at least 21 ToxR-activated genes involved in intestinal colonization (Everiss et al., 1994a). To identify ToxR-activated genes located downstream of the previously characterized ACF genes, a series of overlapping fragments isolated from cloned DNA downstream of the ACF gene cluster were used to perform Northern blot analysis on RNA isolated from the fully virulent classical $V$. cholerae strain O395. ToxR-activated genes are expressed in $V$. cholerae 0395 but are not expressed in KP1.17 due to an insertional disruption in the transcriptional activator ToxR that prevents expression of genes belonging to the ToxR regulon. Except for the tox $\mathrm{R}$ null allele, KP1.17 is otherwise isogenic to strain O395. A recombinant clone was isolated from an O395 genomic library that contained a $16 \mathrm{kbp}$ DNA fragment of the $V$. cholerae chromosome encompassing the acf gene cluster and $\sim 10 \mathrm{kbp}$ of downstream DNA (Fig. 1). Plasmid pMEK1 DNA (Fig. 1) was digested with $B a m \mathrm{HI}$ and EcoRV, and each of the resulting six DNA fragments were isolated, labelled with $\left[{ }^{32} \mathrm{P}\right] \mathrm{dATP}$, and used as probes in RNA slot blot analysis. When the probes generated from the $4.4 \mathrm{kbp} B a m \mathrm{HI}$ DNA fragment (encompassing probes 5 and 6 in Fig. 2) were used in Northern analysis, a hybridization signal was produced in RNA samples isolated from $V$. cholerae $\mathrm{O} 395$ and the ToxR-null strain KP1.17 (Fig. 2). The probes hybridizing to the RNA isolated from the ToxR-null strain indicated

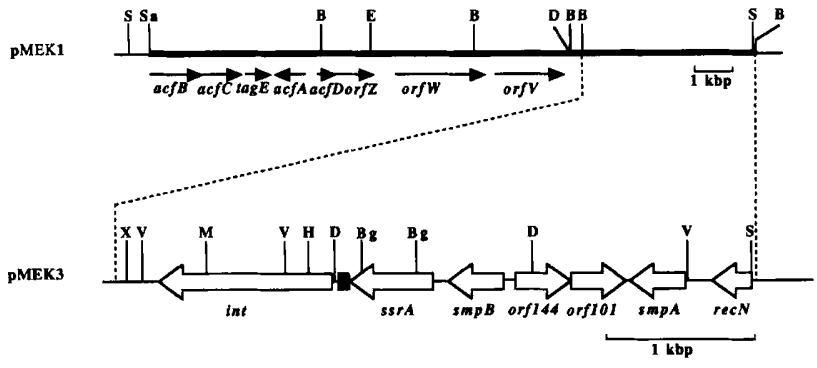

Fig. 1. Physical map of the distal region of the ACF gene cluster. The location of acf and additional genes as determined by DNA sequence analysis are indicated. Arrows denote the direction of transcription and the black box indicates the att site. Restriction sites: B, BamHI; Bg, Bg/II; D, Dral; E, EcoRI; H, HindIII; M, Mscl; S, Sall; Sa, Sau3A; V, EcoRV; X, Xhol.

the existence of transcriptionally active, non-ToxRactivated genes downstream of the acf gene cluster. These constitutively expressed genes mark the distal limit of the $>45 \mathrm{kbp}$ gene cluster encompassing the ToxR-activated TCP and ACF colonization determinants.

\section{Identification, isolation and nucleotide sequence determination of the $V$. cholerae 0395 int gene}

The $4.4 \mathrm{kbp} B a m$ HI DNA fragment from pMEK1 was isolated and ligated into BamHI-digested pBluescript II $\mathrm{KS}^{+}$generating pMEK3 (Fig. 1). The complete nucleotide sequences of pMEK 1 and pMEK 3 were determined using a series of subclones, complementary oligonucleotide primers and exonuclease III deletions (data not shown). Analysis of the nucleotide sequence of pMEK3 revealed a 422 amino acid ORF (Fig. 3) that could encode a protein with a predicted molecular mass of $48.4 \mathrm{kDa}$ and a $\mathrm{pI}$ of $9 \cdot 5$. A polypurine region centred $10 \mathrm{nt}$ upstream of the putative initiation codon was identified (Fig. 3) that may function as a ribosome-binding site (RBS) (Shine \& Dalgarno, 1974; Steitz \& Jakes, 1975) in V. cholerae. Computer-assisted homology searches revealed similarity between the protein encoded by this putative ORF and members of the integrase family of site-specific recombinases. The highest degree of similarity detected, $73 \%$ (52\% identity), was to the E. coli cryptic prophage integrase protein, SlpA (Fig. 4) (Kirby et al., 1994). Based on the level of similarity between the predicted protein and the integrase family of site-specific recombinases, we have designated this $V$. cholerae gene int (integrase). Additionally, the DNA sequence upstream of the $V$. cholerae integrase gene showed identity with the proposed $E$. coli CP4-57 attL site at nineteen of twenty nucleotides (Fig. 5) and showed a significant degree of similarity to the region of the $E$. coli chromosome reported by Miczak et al. (1991) that encodes the 10Sa RNA (ssr A), $\operatorname{smp} B$, $\operatorname{smp} A$ and $\operatorname{rec} N$ gene products (Fig. 1) (Chauhan \& Apirion, 1989; Rostas et al., 1987; Komine et al., 1994). The chromosomal region immediately upstream of the putative $V$. cholerae int shows $79.8 \%$ nucleotide identity with the E. coli $s s r A$, and $89 \%$ and $88 \%$ amino acid 


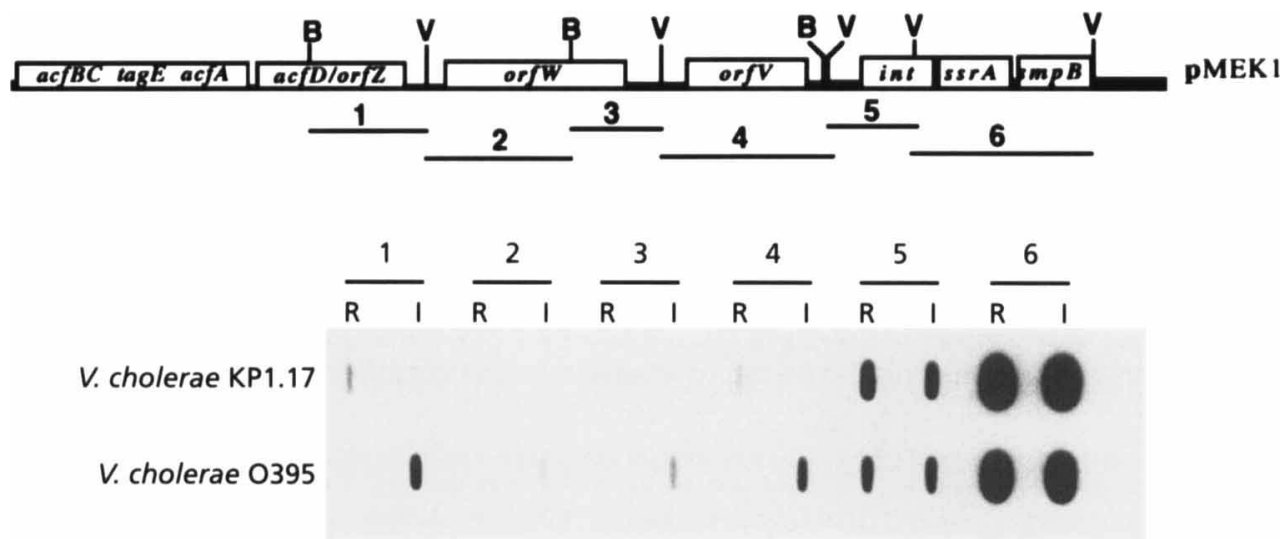

Fig. 2. Slot blot analysis of RNA isolated from $V$. cholerae $O 395$ and KP1.17 under ToxR-regulon-inducing conditions (I) and ToxR-regulon repressing conditions (R). Regions of pMEK1 used as probes are numbered $1-6$ and depicted under the physical map. Probes 5 and 6 identify non-ToxR-activated genes. Restriction sites: B, BamHI; V, EcoRV.

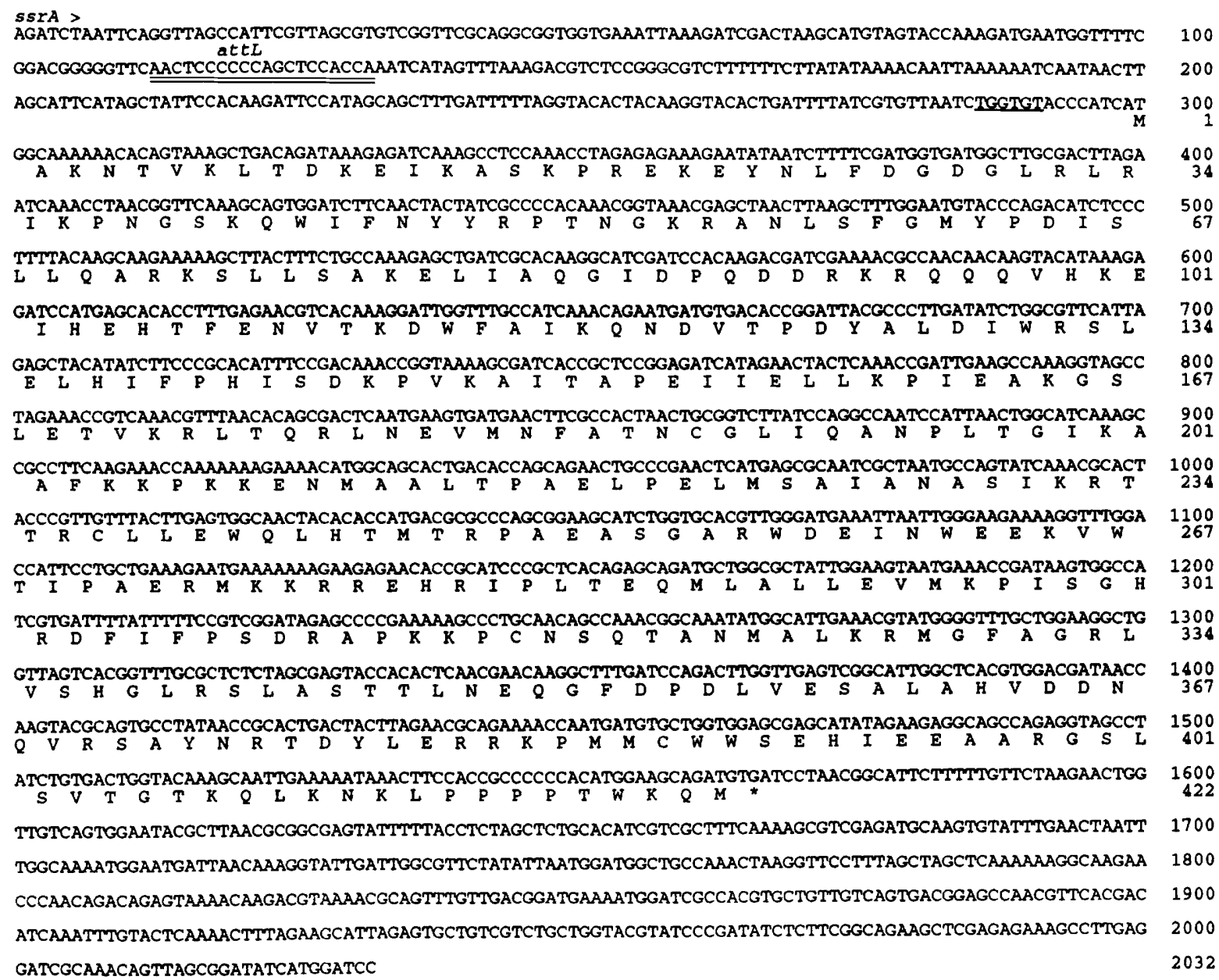

Fig. 3. Nucleotide sequence of a Bg/II-BamHI DNA fragment containing the partial $V$. cholerae 0395 ssrA and int genes and the deduced integrase amino acid sequence. The underlined segment indicates the putative ribosome-binding site and the double-underlined region indicates the putative attL site. The translation stop codon (TGA) is indicated by *.

similarity to E. coli $\mathrm{SmpB}$ and $\mathrm{SmpA}$, respectively (data not shown). Further analysis has shown that the nonToxR-activated transcript detected in slot blot analysis
(Fig. 2) originates immediately upstream of the integrase and corresponds to the $V$. cholerae equivalent of the $10 \mathrm{Sa}$ RNA $(\operatorname{ssr} A)$ 


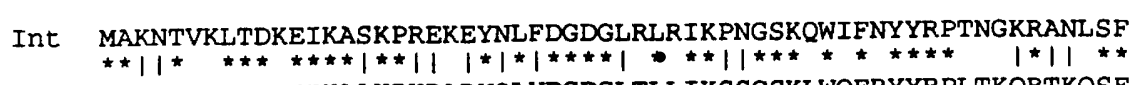
SIPA MARKTKPLTDTEIKAAKPKDADYQLYDGDGLTLLIKSSGSKLWQFRYYRPLTKQRTKQSF

Int GMYPDISLLQARKSLLSAKELIAQGIDPQDDRKRQQQVHKEIHEHTFENVTKDWFAIKQN

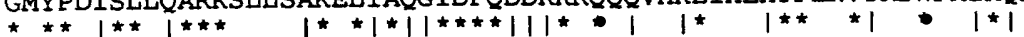
SIPA GAYPAVSLSDARKLRAESKVLLAKDIDPQEHQKEQVRNSQEAKTNTFLLVAERWWNVKKT

Int DVTPDYALDIWRSLELHIFPHISDKPVKAITAPEI IELLKPIEAKGSLETVKRLTQRLNE

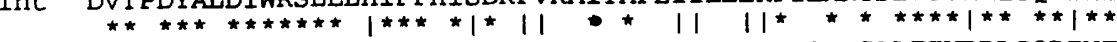
SIPA SVTEDYADDIWRSLERDIFPAIGDISITEIKAHTLVKAVOPVQARGALETVRRLCQRINE

Int VMNFATNCGLIQANPLTGIKAAFKKPKKENMAALTPAELPELMSAIANASIKRTTRCLLE

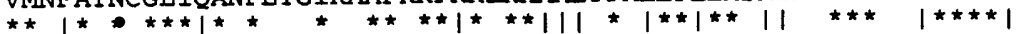

SIPA VMIYAQNTGLIDAVPSVNIGKAFEKPQKKNMPSIRPDQLPQLMHTMRTASISMSTRCLFM 240

Int WQLHTMTRPAEASGARWDEINWEEKVWTIPAERMKKRREHRIPLTEQMLALLEVMKPISG

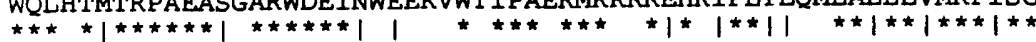
SIPA WQLLTITRPAEAAEARWDEIDFNASEWKI PAARMKMNRDHTVPLSDGALAILEMMKPLSG

$++$

Int HRDFIFPSDRAPKKPCNSQTANMALKRMGFAGRLVSHGLRSLASTTLNEQGFDPDLVESA

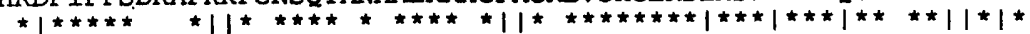

SIPA GREFIFPSRIKPNQPMNSQTVNAALKRAGLGGVLVSHGLRSIASTALNEEGFPPDVIEAA 360

Int LAHVDDNQVRSAYNRTDYLERRKPMMCWWSEHIEEAARGSLSVTGTKQLKNKLPPPPTWK

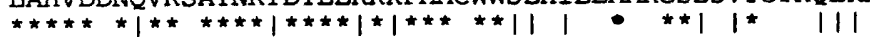

SIPA LAHVDKNEVRRAYNRSDYLEQRRPMMQWWADLVKAADSGSIVLTHLSKIR

Int $\mathrm{QM}$
60 60

120

180 180

240

300

300

360

420

410

422

Fig. 4. Computer-assisted alignment of the $V$. cholerae $O 395$ integrase (Int) predicted amino acid sequence with the $E$. coli CP4-57 cryptic prophage integrase (SIpA) amino acid sequence (Kirby et al., 1994). Numbers on the right of the amino acid residues indicated the residue number. Identical matches $(52 \%)$ are indicated by * and conservative changes $(21 \%)$ are indicated by |. The amino acids that are conserved in the P4 family of integrase proteins that are believed to be part of the catalytic domain (Argos et al., 1986; Abremski \& Hoess, 1992) are indicated by + .

\section{E. $\operatorname{coli} \operatorname{CP} 4-57$ \\ V. cholerae 0395 \\ V. cholerae 1074-78 \\ V. cholerae SG34}

AACTCCCGCCAGCTCCACCA
1
AACTCCCCCCAGCTCCACCA
AACTCCCCCCAGCTCCACCA
$\vdots$
AAATCCCCCCAGCTCCACCA

Fig. 5. Comparison of the putative attL sites from $E$. coli and $V$. cholerae O395, 1074-78 and SG34. The base pair mismatch between $V$. cholerae 0395 and $E$. coli is indicated by | and the base pair mismatch between $V$. cholerae 01 (0395 and 1074-78) and non-O $1 \mathrm{~V}$. cholerae SG34 is indicated by $\neq$.

\section{Identification of int sequences in El Tor and 0139 strains of $V$. cholerae}

To ascertain if the integrase gene and surrounding sequences were unique to $V$. cholerae classical strain $\mathrm{O} 395$, slot blot analysis was performed on 13 additional $V$. cholerae strains. DNA fragments specific for tagD (Hughes et al., 1994), tcpI (Harkey et al., 1994), toxT (Higgins $e$ t al., 1992), acf (Peterson \& Mekalanos, 1988) as well as the int and $\operatorname{ss} A$ genes were used to determine if these sequences were conserved in recent $V$. cholerae O1 El Tor and nonO1 isolates. Chromosomal DNA from eight O1 (seven El Tor, one classical), three O139 and three non-O1 strains were analysed. Slot blot analysis (Fig. 6) demonstrated that DNA isolated from nine of the $V$. cholerae strains tested generated a hybridization signal when analysed with all six probes. Four of the five $V$. cholerae strains that failed to hybridize with all but the $s s r A$-specific probe are nonpathogenic (Levine et al., 1982; Morris, 1990). Analysis of the ssr $A$ region from the nonpathogenic O1, El Tor $V$. cholerae strain 1074-78 revealed that numerous base pair substitutions, insertions and deletions have occurred in the DNA sequence between the ssr $A$ and int genes (data not shown). The ssr $A$ region of the non-O1 $V$. cholerae SG34 chromosome has also been cloned (data not shown) and the nucleotide sequence of the region downstream of the $\operatorname{ss} A$ gene determined. A single $C$ to $A$ transversion was noted between the $V$. cholerae $\mathrm{O} 395$ and SG34 att-like sites (Fig. 5). The nucleotide sequence alignment between $\mathrm{O} 395$ and SG34 ends at the last A residue of the proposed att site and no int sequences were observed (data not shown). In slot blot analysis a probe derived from $\phi 19$ (Table 1), encompassing the DNA downstream of the SG34 ssr $A$ gene, hybridized to chromosomal DNA from 

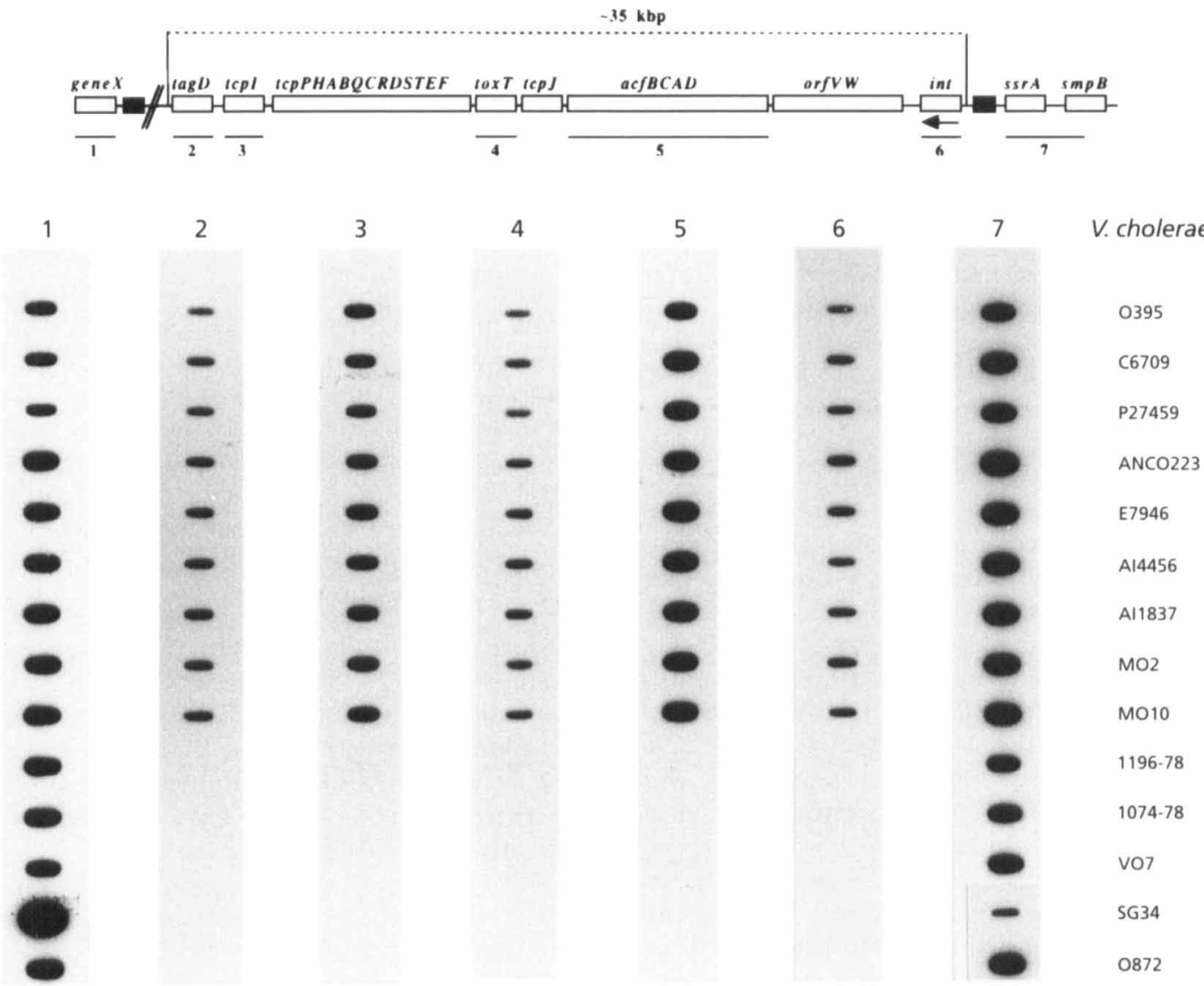

Fig. 6. Physical map depicting the regions of the $V$. cholerae chromosome that were used as probes in the slot blot analysis on chromosomal DNA isolated from $14 \mathrm{~V}$. cholerae strains. Probes 2-7 were derived from V. cholerae 0395 and probe 1 was derived from $V$. cholerae SG34. The black boxes indicate the att-like sequences. The arrow indicates the direction of transcription of the integrase gene.

all $14 V$. cholerae strains tested (Fig. 6, probe 1). This probe did not hybridize with a recombinant phage, $\phi \mathrm{D} 12$ 2 (Table 1 ) that contains $\sim 10 \mathrm{kbp}$ of $V$. cholerae DNA sequences upstream of $\operatorname{tag} D$ (data not shown). Since there is $\sim 35 \mathrm{kbp}$ of DNA sequence between $\operatorname{tag} D$ and int, the absence of hybridization between the SG34 derived probe and $\phi \mathrm{D} 12-2$ indicates that the $V$. cholerae chromosomal element encompassing the ToxR-regulated TCP-ACF colonization determinants is greater than $45 \mathrm{kbp}$. We are currently isolating overlapping recombinant bacteriophage clones in order to identify the proximal end of the TCP-ACF gene cluster.

\section{DISCUSSION}

Our efforts to define the distal limit of the $V$. cholerae ToxR-regulated gene cluster consisting of the TCP and ACF colonization determinants have led to the identification of a linked gene that belongs to the integrase family of site-specific recombinases. The $I$. cholerae integrase lies next to a gene $(\operatorname{ss}, A)$ encoding the $V$. cholerae equivalent of the E. coli $10 \mathrm{Sa}$ RNA. Based on the constitutive level of expression of $\operatorname{ss} A$, we have defined this region as the end of the ToxR-regulated TCP-ACF gene cluster. Slot blot analysis of DNA isolated from $V$. cholerae $\mathrm{O} 1$ and non-O1 strains has revealed that the region of the $V$. cholerae chromosome encoding TCP, $\mathrm{ACF}$ and the integrase is present in the Asiatic-choleracausing strains but absent from the non-cholera vibrio strains tested.

The putative $V$. cholerae integ rase shows significant amino acid similarity with the P4 family of integrases (Argos et al., 1986). These catalyse site-specific integration via DNA nicking and strand exchange that is mediated through a conserved catalytic domain within the carboxy-terminus of the integrase protein (Argos et al., 1986; Landry, 1989). The $V$. cholerae integrase contains the four highly conserved catalytic domain residues (Fig. 4) (Argos et al., 1986; Abremski \& Hoess, 1992) and shows the highest degree of amino acid similarity $(73 \%)$ with the $E$. coli CP4-57 cryptic prophage integrase, SlpA. In addition to the extensive amino acid similarity between these two proteins, $V$. cholerae and $E$. coli show nucleotide identity at nineteen of twenty positions within the attL-like site upstream of the $V$. cholerae integrase and the CP4-57 attL site. Both the $V$. cholerae and $E$. coli $\mathrm{CP} 4-57$ integrase 
genes are located at very similar chromosomal sites i.e. downstream of the gene $(s s r A)$ that encodes the $10 \mathrm{Sa}$ small stable RNA, further reinforcing the similarity between these systems and these two proteins.

Several lines of evidence suggest that the $V$. cholerae tcp, acf and int are part of a genetic element that encompasses $>45 \mathrm{kbp}$ of the $V$. cholerae chromosome. The atypical codon bias reported by Ogierman \& Manning (1992) for the TCP genes led them to suggest that the TCP gene cluster was either recently acquired or was non- $V$. cholerae in origin. Our studies indicate that the TCP-ACF gene cluster is located in a region of the $V$. cholerae chromosome that is analogous to the E. coli CP4-57 cryptic prophage integration site (Kirby et al., 1994). When chromosomal DNA from 14 strains of $V$. cholerae was examined by slot blot analysis for the presence of tcp, acf and int sequences, an interesting pattern of hybridization was observed. The $V$. cholerae $\mathrm{O} 1$ and $\mathrm{O} 139$ strains that have been associated with Asiatic cholera hybridized to the $t c p$-, acf- and intspecific probes whereas the non-O1 and nonpathogenic O1 strains hybridized only to the area of the $V$. cholerae chromosome that flanked the ToxR-regulated TCP and ACF gene clusters. When the $s s r A$ region of the chromosome from $V$. cholerae 1074-78, a nonpathogenic O1 strain that did not hybridize to the tcp-, acf- or intspecific probes, was examined, only the $5^{\prime}$ portion of the integrase gene was present in this strain and numerous base pair substitutions, insertions and deletions were noted between the $s s r A$ and int, as well as within the portion of the int gene that was present. The presence of multiple base pair changes within the intervening DNA sequence of the integrase and 10Sa RNA is similar to that which frequently occurs when prophage undergo partial deletion or illegitimate recombination (Campbell, 1992, 1994). Our sequence data indicate that a similar phenomenon may have occurred in $V$. cholerae 1074-78. V. cholerae SG34 is a non-cholera non-O1 strain that lacks tcp, acf and any residual portions of the integrase gene near the $s s r A$ region. This strain however, contains an intact att site suggesting that SG34 has never acquired the tcp, acf and int genes. These observations, taken together with the fact that the TCP-ACF gene cluster possesses a gene (toxT) encoding a transcriptional activator (ToxT) necessary for TCP-ACF gene expression leads us to believe that the TCP-ACF gene cluster was at one time part of a large mobile genetic element.

Karaolis et al. (1995) have proposed, on the basis of polymorphisms within the $V$. cholerae housekeeping gene encoding the aspartate-semialdehyde dehydrogenase (asd), that the O1 serogroup may arise from nontoxigenic, non-O1 $V$. cholerae via the horizontal transfer of the $\mathrm{O}$ antigen. A similar horizontal transfer of the element containing the TCP and ACF colonization determinants may have occurred, possibly via a mechanism that is similar to that shown for the $17 \mathrm{kbp}$ mobile genetic element (SLP1) of Streptomyces coelicolor. The SLP1 element can undergo excision, conjugal transfer and subsequent site-specific integration into the chromosome of recipient $S$. coelicolor cells (Omer \& Cohen, 1984). We are currently attempting to develop an in vitro system to determine if transfer of the $t c p$-acf-int region from the $V$. cholerae chromosome can occur between $V$. cholerae strains in a similar manner. Preliminary mating experiments between $V$. cholerae $\mathrm{O} 395\left(t c p^{+} a c f^{+} i n t^{+}\right)$and $V$. cholerae VO7 (tcp acf int) have not resulted in the transfer of the TCP-ACF gene cluster from pathogenic to nonpathogenic vibrios. These results may not be surprising since we have failed to detect an int transcript under a variety of different culture conditions (data not shown). In E. coli, a small basic protein (AlpA) has been identified that can act as a positive regulator of $s l p A$ (integrase) expression. Overexpression of AlpA results in an increase in transcription of $\operatorname{sl} p A$, which subsequently leads to excision of the CP457 prophage from the E. coli chromosome (Trempy et al., 1994; Kirby et al., 1994). A similar activator protein may be required for expression of the $V$. cholerae integrase and the subsequent excision or transfer of this element from the $V$. cholerae chromosome.

Future studies will attempt to overexpress int in the donor strain $\left(t c p^{+} a c f^{+}\right)$to determine if the integrase protein can promote excision of the TCP-ACF gene cluster from the att-like site downstream of the $V$. cholerae equivalent of the $\operatorname{ss} A$ gene. Additional studies will focus on delineating the proximal end of the TCP-ACF element. Isolation of the intact TCP-ACF element using a modified form of the in vivo excision system developed by Pósfai et al. (1994), which allows the cloning of large $(50-100 \mathrm{kbp})$ regions of the bacterial chromosome, may permit the size and limits of this element to be clearly defined and help identify the number of genes present within the TCP-ACF element. Isolation of the intact TCP-ACF element will also allow studies to be performed in which these colonization factors are introduced into non-O1, noncholera vibrios that possess toxR but lack TCP-ACF sequences such as $V$. cholerae VO7 (Waldor \& Mekalanos, 1994). These recombinant $V$. cholerae strains can then be tested for their ability to express TCP and ACF, and colonize the intestines of infant mice. The introduction of the TCPACF colonization element into nonreactogenic strains of $V$. cholerae may thus provide an avenue for generating efficacious live vaccine candidates.

\section{ACKNOWLEDGEMENTS}

We thank D. T. Beattie, M. Waldor and J. B. Kaper for the kind gifts of $V$. cholerae strains, C. S. Harwood for pHRP309, S. Gottesman for pJK5 and pJT27, D. Friedman for sharing results prior to publication, and V. J. DiRita and P. Zuber for helpful comments. This work was supported by Public Health services grant AI28502 from the National Institutes of Health and the LSUMC Center for Excellence in Cancer Research, Treatment and Education.

\section{REFERENCES}

Abremski, K. E. \& Hoess, R. H. (1992). Evidence for a second conserved arginine residue in the integrase family of recombination proteins. Prot Eng 5, 87-91.

Aiba, H., Adhya, S. \& deCrombrugghe, B. (1981). Evidence for two functional gal promoters in intact Escherichia coli cells. $J$ Biol Cbem 256, 11905-11910. 
Altschul, S. F., Gish, W., Miller, W., Myers, E. W. \& Lipman, D. J. (1990). Basic local alignment search tool. J Mol Biol 215, 403-410.

Argos, P., Landy, A., Abremski, K., Egan, J. B., HaggardLjungquist, E., Hoess, R. H., Kahn, M. L., Kalionis, B., Narayana, S. V. L., Pierson, L. S., III, Sternberg, N. \& Leong, J. M. (1986). The integrase family of site-specific recombinases: regional similarities and global diversity. EMBO J 5, 433-440.

Ausubel, F. M., Brent, R., Kingston, R. E., Moore, D. D., Seidman, J. G., Smith, J. A. \& Struhl, K. (1989). Current Protocols in Molecular Biology. New York: John Wiley.

Baudry, B., Fasano, A., Ketley, J. \& Kaper, J. B. (1992). Cloning of a gene (zot) encoding a new toxin produced by $\mathrm{L}$ ibrio cholerae. Infect Immun 60, 428-434.

Campbell, A. M. (1992). Chromosomal insertion sites for phages and plasmids. J Bacteriol 174, 7495-7499.

Campbell, A. (1994). Comparative molecular biology of lambdoid phages. Annu Rev Microbiol 48, 193-222.

Chauhan, A. K. \& Apirion, D. (1989). The gene for a small stable RNA (10Sa RNA) of Eschericbia coli. Mol Microbiol 3, 1481-1485.

DiRita, V. J. (1992). Co-ordinate expression of virulence genes by ToxR in I'ibrio cholerae. Mol Microbiol 6, 451-458.

DiRita, V. J., Parsot, C., Jander, G. \& Mekalanos, J. J. (1991). Regulatory cascade controls virulence in $\mathrm{V}$ ibrio cholerae. Proc Natl Acad Sci US.A 88, 5403-5407.

Everiss, K. D., Hughes, K. J. \& Peterson, K. M. (1994a). The accessory colonization factor and toxin-coregulated pilus gene clusters are physically linked on the I'ibrio cholerae $\mathrm{O} 395$ chromosome. DN A Seq 5, 51-55.

Everiss, K. D., Hughes, K. J., Kovach, M. E. \& Peterson, K. M. (1994b). The Vibrio cholerae acf $B$ colonization determinant encodes an inner membrane protein that is related to a family of signaltransducing proteins. Infect Immun 62, 3289-3298.

Fasano, A., Baudry, B., Pumplin, D. W., Wasserman, S. S., Tall, B. D., Ketley, J. M. \& Kaper, J. B. (1991) I ibrio cholerae produces a second enterotoxin which affects intestinal tight junctions. Proc Natl Acad Sci US. A 88, 5242-5246.

Finlay, B. B. \& Falkow, S. (1989). Common themes in microbial pathogenicity. Microbiol Rev 53, 210-230.

Harkey, C. W., Everiss, K. D. \& Peterson, K. M. (1994). The I ibrio cholerae toxin-coregulated-pilus gene tcpI encodes a homolog of methyl-accepting chemotaxis proteins. Infect Immun 62, 2669-2678.

Higgins, D. E., Nazareno, E. \& DiRita, V. J. (1992). The virulence gene activator ToxT from Librio cholerae is a member of the $\mathrm{AraC}$ family of transcriptional activators. J Bacteriol 174, 6974-6980.

Hughes, K. J., Everiss, K. D., Harkey, C. W. \& Peterson, K. M. (1994). Identification of a Vibrio cholerae ToxR-activated gene $(\operatorname{tag} D)$ that is physically linked to the toxin-coregulated pilus $(t c p)$ gene cluster. Gene 148, 97-100.

Karaolis, D. K. R., Lan, R. \& Reeves, P. R. (1995). The sixth and seventh cholera pandemics are due to independent clones separately derived from environmental, nontoxigenic, non-O1 Vibrio cholerae. J Bacteriol 177, 3191-3198.

Kaufman, M. R., Shaw, C. E., Jones, I. D. \& Taylor, R. K. (1993). Biogenesis and regulation of the L'ibrio cholerae toxin-coregulated pilus: analogies to other virulence factor secretory systems. Gene 126, 43-49.

Kirby, J. E., Trempy, J. E. \& Gottesman, S. (1994). Excision of a P4like cryptic prophage leads to Alp protease expression in Escherichia coli. J Bacteriol 176, 2068-2081.

Komine, Y., Kitabatake, M., Yokogawa, T., Nishikawa, K. \& Inokuchi, H. (1994). A tRNA-like structure is present in 10Sa RNA, a small stable RNA from Escherichia coli. Proc Natl Acad Sci US A 91, 9223-9227.

Landry, A. (1989). Dynamic, structural and regulatory aspects of isite-specific recombination. Annu Rev Biocbem 58, 913-949.

Levine, M. M., Black, R. E., Clements, M. L., Cisneros, L., Saah, A., Nalin, D. R., Gill, D. M., Craig, J. P., Young, C. R. \& Ristaino, P. (1982). The pathogenicity of nonenterotoxigenic Librio cholerae serogroup O1 biotype El Tor isolated from sewage water in Brazil. J Infect Dis 145, 296-299.

Miczak, A., Chauhan, A. K. \& Apirion, D. (1991). 'Two new genes located between 2758 and 2761 kilobase pairs on the Escherichia coli genome. J Bacteriol 173, 3271- 3272.

Miller, J. H. (1972). Experiments in Molecular Genetics. Cold Spring Harbor, NY: Cold Spring Harbor Laboratory.

Miller, V. L. \& Mekalanos, J. J. (1984). Synthesis of cholera toxin is positively regulated at the transcriptional level by tox R. Proc Natl Acad Sci US A 81, 3471-3475.

Miller, V. L. \& Mekalanos, J. J. (1988). A novel vector and its use in construction of insertion mutations: osmoregulation of outer membrane proteins and virulence determinants in Vibrio cholerat requires tox $R$. J Bacteriol 170, 2575-2583.

Morris, J. G. (1990). Non-O group 1 L'ibrio cholerae: a look at the epidemiology of an occasional pathogen. Epidemiol Rev 12, 179-191. Ogierman, M. A. \& Manning, P. A. (1992). Homology of TcpN, a putative regulatory protein of Vibrio cholerae, to the AraC family of transcriptional activators. Gene 116, 93-97.

Omer, C. A. \& Cohen, S. N. (1984). Plasmid formation in Streptomyces: excision and integration of the SLP1 replicon at a specific chromosomal site. Mol Gen Genet 196, 429-438.

Parsot, C. \& Mekalanos, J. J. (1991). Expression of the Vibrio cholerae gene encoding aldehyde dehydrogenase is under control of ToxR, the cholera toxin transcriptional activator. I Bacteriol 173, 2842-2851.

Parsot, C. \& Mekalanos, J. J. (1992). Structural analysis of the acf $A$ and acfD genes of L'ibrio cholerat: effects of DNA topology and transcriptional activators on expression. J Bacteriol 174, 5211-5218.

Pearson, G. D. N., Woods, A., Chiang, S. L. \& Mekalanos, J. J. (1993). CTX genetic element encodes a site-specific recombination system and an intestinal colonization factor. Proc Natl Acad Sci US A 90, 3750-3754.

Peterson, K. M. \& Mekalanos, J. J. (1988). Characterization of the Vibrio cholerae ToxR regulon: identification of novel genes involved in intestinal colonization. Infect Immun 56, 2822-2829.

Pósfai, G., Koob, M., Hradecná, Noaman, H., Filutowicz, M. \& Szybalski, W. (1994). In vivo excision and amplification of large segments of the Eschericbia coli genome. Nucleic Acids Res 22, 2392-2398.

Rostas, K., Morton, S. J., Picksley, S. M. \& Lloyd, R. G. (1987). Nucleotide sequence and LexA regulation of the Escherichia coli recN gene. Nucleic Acids Res 15, 5041-5049.

Sambrook, J., Fritsch, E. F. \& Maniatis, T. (1989). Molecular Cloning: a Laboratory Manual. Cold Spring Harbor, NY : Cold Spring Harbor Laboratory.

Sanger, F., Nicklen, S. \& Coulson, A. R. (1977). DNA sequencing with chain-terminating inhibitors. Proc Natl Acad Sci USA 74, 5463-5467.

Shine, J. \& Dalgarno, L. (1974). The 3 '-terminal sequence of Escherichia coli $16 \mathrm{~S}$ ribosomal RNA: complementarity to nonsense triplets and ribosome binding sites. Proc Natl Acad Sci USA 71, 1342-1346.

Steitz, J. A. \& Jakes, K. (1975). How ribosomes select initiator 
regions in mRNA: base pair formation between the $3^{\prime}$ terminus of $16 \mathrm{~S}$ rRNA and the mRNA during initiation of protein synthesis in Eschericbia coli. Proc Natl Acad Sci US A 72, 4734-4738.

Taylor, R. K., Miller, V. L., Furlong, D. B. \& Mekalanos, J. J. (1987). Use of $p$ bo $A$ gene fusions to identify a pilus colonization factor coordinately regulated with cholera toxin. Proc Natl Acad Sci US A 84, 2833-2837.

Trempy, J. E., Kirby, J. E. \& Gottesman, S. (1994). Alp suppression of Lon: dependence on the slpA gene. J Bacteriol 176, 2061-2067.

Trucksis, M., Galen, J. E., Michalski, J., Fasano, A. \& Kaper, J. B. (1993). Accessory cholera enterotoxin (Ace), the third toxin of a
Vibrio cholerae virulence cassette. Proc Natl Acad Sci USA 90 , 5267-5271.

Waldor, M. K. \& Mekalanos, J. J. (1994). ToxR regulates virulence gene expression in non-O1 strains of Vibrio cholerae that cause epidemic cholera. Infect Immun 62, 72-78.

Yanisch-Perron, C., Vieira, J. \& Messing, J. (1985). Improved M13 phage cloning vectors and host strains: nucleotide sequences of the M13mp18 and pUC19 vectors. Gene 33, 103-119.

Received 16 October 1995; revised 20 February 1996; accepted 13 March 1996. 